\title{
中耳根本手術の推移
}

$\begin{array}{lrlll}\text { 村田 } & \text { 清高・木村 } & \text { 裕毅・東 } & \text { 博二・石川 } & \text { 雅洋 } \\ \text { 竹山 } & \text { 豊・太根 } & \text { 洋史・太田 } & \text { 文彦 }\end{array}$

\section{Reconstruction of Middle Ear in Radical Mastoidectomy}

\author{
Kiyotaka Murata, Hiroki Kimura, Hiroji Azuma, Masahiro Ishikawa, \\ Yutaka Takeyama, Hiroshi Tane and Fumihiko Ohta \\ (Kinki University School of Medicine)
}

A statistical analysis was performed on 61 patients who underwent radical mastoidectomy at our clinic between May, 1977 and March, 1990.

Epipharynx was intact in 45 patients. Nose and paranasal sinuses were intact in 43 patients. Tympanic tubal orifice was closed in 17 ears, but only 4 dry ears were obtained the others being inflammatory and/or recurrent cholesteatoma. The tympanic tubal orifice need not be surgically closed.

The middle ear was reconstructed in 12 ears and all of them showed dry ears. The middle ear was not reconstructed but the tympanic tubal orifice was closed in 17 ears, 4 of which showed dry ears. The middle ear was not reconstructed, but tympanic tubal orifice was closed in 32 ears, 19 of which showed dry ears. The middle ear cleft should be reconstructed when there is buried mucosa which leads to cystic formation and results in recurrent inflammatory ears.

Reconstruction of the middle ear is recommended even in radical mastoidectomy.

Key words: radical mastoidectomy, tympanic tubal orifice, reconstruction, middle ear

\section{はじめに}

現在では，中耳根本手術は過去の手術ともい われている。しかし，実際には止むを得ず選択 する場合がある。(1)なぜ根本手術を選んだのか， (2)根本手術後は常に乾燥耳が得られるのか, (3) 鼻副鼻腔, 上咽頭の炎症の少なくなった今日で も耳管鼓室口の骨性閉鎖を行うといら考え方で よいのか, (4)両耳聴効果がない場合根本手術を 選択するといら考えではいけないのか，などの 疑問もある.

以上のよらな考光から中耳根本手術の実際を
しらべ，現在における本術式の適応，問題点を 整理することにした。

\section{対 象}

昭和 52 年 5 月初めから平成 2 年 3 月末までの 間に近畿大学医学部耳鼻咽喉科学教室で行われ た中耳根本手術は新鮮例61耳であった。男33名, 女28名, 右耳42, 左耳19（表 1 ）で, 年齢分布 は種々の年齢にわたっているが，30歳代にピー クがあった（図 1 ）。30，40歳代で61例中33例 （54. 1\%）を占めている. 


\section{結 果}

疾患の内訳は真珠腫が47耳, 慢性化膿性中耳 炎が11耳, 鼓室硬化症 2 耳, その他であった（表 2 ). 聴力は 3 分法平均を採用した.

1. 中耳根本手術選択の理由

なぜ中耳根本手術を選んだのか，その理由を 表 3 に示す。襲むるいは $41 \mathrm{~dB}$ 以上の骨尊低下 のため実用聴力が期待できない例は31耳あった。 その他, 迷路瘦孔 6 耳, 真珠腫残存の疑い 7 耳, 内耳炎 4 耳，耳管閉鎖 3 耳，内耳空不動 2 耳, などが主な理由であった。

2.上咽頭，副鼻腔の所見

上咽頭は異常なしが61耳中45耳で発赤腫脹は わずか 3 例であった。不明が11耳市ったが鼻咽 頭の症状があるといら記載はなかった（表4）。

副番腔炎は 5 耳, 鼻炎は 7 耳に見られたが 43 耳には異常がなかった（表5）。

3. 手術法と再発

自験例を見ると（表 6 ），耳管豉室口を骨性 に閉鎖すべく処置した17耳のうち長期乾燥耳が 得られたのは 4 耳のみで, 湿潤 3 耳, 化膿性 2

表 1 性別，䍜患側

\begin{tabular}{rrrr}
\hline \hline & 男 & 女 & 計 \\
\hline 右 & 22 & 20 & 42 \\
左 & 11 & 8 & 19 \\
\hline 計 & 33 & 28 & 61
\end{tabular}

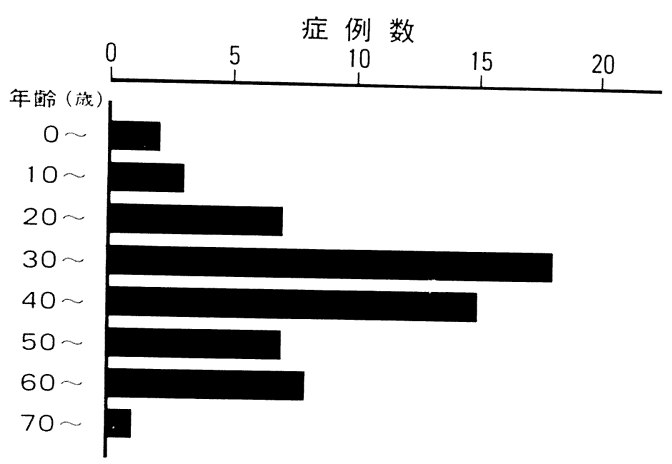

図1 年路分布
耳, 真珠腫 3 耳, 耳垢・痂皮 4 耳, 一部湿潤 1 耳であった，耳管鼓室口を意識して閉鎖しなか った 32 耳では，19耳で乾燥，4耳で化膿性，1 耳で再発真珠腫，1耳で耳垢・痂皮，3耳で一 部湿潤であった。

4. 患側骨導と対側気導の差（術前）

患側骨導と対側気導の差が $30 \mathrm{~dB}$ 以内のもの は術側骨導閾值 $41 \mathrm{~dB}$ 以上が 15 耳， $40 \mathrm{~dB}$ 以内

表 2 疾患別症例数

\begin{tabular}{lr}
\hline \hline 真珠腫 & 47 \\
慢性化膿性中耳炎 & 11 \\
攱室硬化症 & 2 \\
慢性化膿性中耳炎十腫㨨 & 1 \\
\hline \multicolumn{1}{c}{ 計 } & 61
\end{tabular}

表 3 中耳根本手術選択の理由

\begin{tabular}{|c|c|}
\hline 䘄あるいは $41 \mathrm{~dB}$ 以上の骨噂低下 & 31 \\
\hline 揬孔後の合併疑い & 6 \\
\hline 真珠腫残存の疑い & 7 \\
\hline 内耳人の炎症波及 & 4 \\
\hline 耳管閉鎖 & 3 \\
\hline 内耳空不動 & 2 \\
\hline その他 & 8 \\
\hline
\end{tabular}

表 4 上咽頭の所見

\begin{tabular}{|c|c|}
\hline 異常なし & 45 \\
\hline 発赤腫脤 & 3 \\
\hline 滲出液, 膿 & 2 \\
\hline 不 明 & 11 \\
\hline
\end{tabular}

表 5 兵副鼻腚の所見

\begin{tabular}{cc}
\hline \hline 異常なし & 43 \\
泉炎 & 7 \\
副鼻腔炎 & 5 \\
不 明 & 6 \\
\hline
\end{tabular}


が 27 耳であった。対側気尊との間に $30 \mathrm{~dB}$ 以上 の差があった例は16耳であった。

5 . 中耳根本手術症例の推移

図 2 に我々の臨床での中耳根本手術症例の推 移を示した。

\section{考察}

1. 中耳根本手術選択の理由

なぜ根本手術を選んだのか，その理由を示し た表 3 をみると，鄣あるいは $41 \mathrm{~dB}$ 以上の骨脜

表 6 手術法と再発

\begin{tabular}{|c|c|c|c|}
\hline \multirow{3}{*}{ 耳内所見 } & \multicolumn{3}{|c|}{ 手 術法 } \\
\hline & \multirow[t]{2}{*}{ 鼓膜再建あり } & \multicolumn{2}{|c|}{$\begin{array}{c}\text { 㩽膜再建な } \\
\text { 耳管口処㯰 } \\
\end{array}$} \\
\hline & & 閉鎖せず & 閉鎖 \\
\hline 乾 燥 & 12 & 19 & 4 \\
\hline 化膿性 & & 4 & 2 \\
\hline 耳坼, 痂皮 & & 1 & 4 \\
\hline 真珠腫 & & 1 & 3 \\
\hline 一部の久湿澗 & & 3 & 1 \\
\hline 湿＼cjkstart澗 & & 1 & 3 \\
\hline 不 明 & & 3 & \\
\hline 計 & 12 & 32 & 17 \\
\hline
\end{tabular}

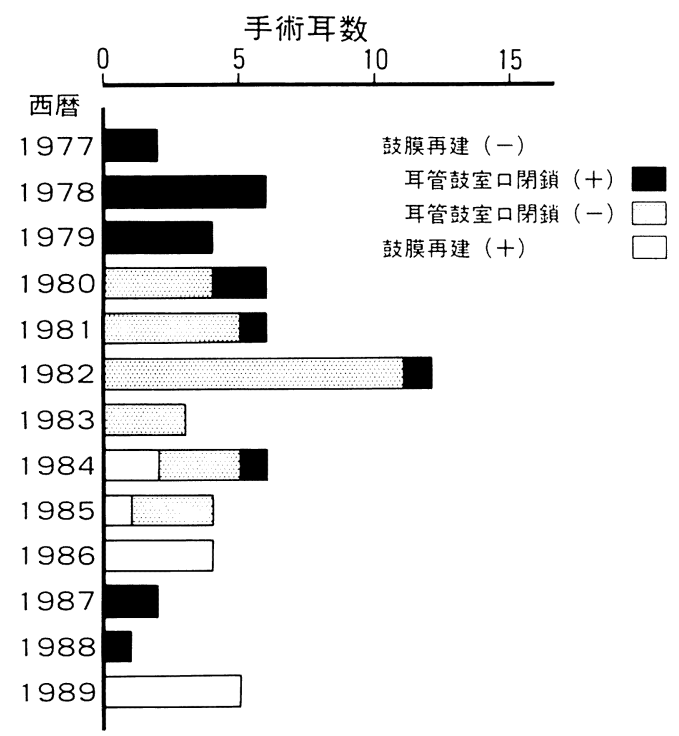

図 2 中耳根本手術症例の推移
低下のため実用聴力が期待できない場合，真珠 腫では再発のおそれを考慮すると根本手術を行 ら方が得策と考支て選択したものが最も多い。 しかし, 根本手術後は常に乾燥耳が得られるの か，といら疑問もある。根本手術の場合でも蜂 巣は残存する可能性が大であり, 結合組織に埋 まった状態でいったん乾いたあと, 残存蜂巣は 換気，ドレナージの道がなく，術後創面がしば しば湿閵となり，そのあと手を尽くしても乾燥 しないことがある11. 中耳根本手術は聴力を考 慮しない手術であるばかりでなく炎症を消失さ せるための手術としても理論的根拠に欠ける点 があることがわかる。

\section{2 .上咽頭, 副鼻腔の所見}

鼻副鼻腔，上咽頭の炎症の少なくなった今日 でも耳管鼓室口の骨性閉鎖を行らといら考え方 でよいのか，という問題を考えてみる.

耳管豉室口の骨性閉鎖は上咽頭, 鼻の炎症が 頻繁に見られた時代に，上咽頭，鼻上り鼓室に およぶ炎症をブロックする目的で行われたもの である。しかし, 最近の中耳炎, 真珠腫では, 上咽頭，鼻の炎症所見が耳管を閉鎖しなければ ならない活どひどいといら印象は少ない。この 点を検討するため上咽頭炎，鼻副鼻腔炎の有無 をしらべた，表 4，5から，上咽頭，鼻副鼻腔 より耳管を介して中耳に感染が繰り返されるの を防ぐといら日的で耳管鼓室口を骨性閉鎖する といら意義は少ないと考える。

また，含気蜂巣の解剖からいらと耳管鼓室口 を閉じるのは残存含気蜂巣の換気，ドレナージ にとって不合理な術後形態を作り出すことにも なる112)ので，この意味からも耳管鼓室口を骨

表 7 患側骨導と対側父導の差（術前）

\begin{tabular}{lr}
\hline \hline $30 \mathrm{~dB}$ 以内 & \\
術前骨尊閾值 $41 \mathrm{~dB}$ 以上 & 15 耳 \\
術前骨·導閾値 $40 \mathrm{~dB}$ 以内 & 27 耳 \\
$30 \mathrm{~dB}$ 以上 & 16 耳 \\
不 明 & 3 耳 \\
\hline \multicolumn{1}{c}{ 計 } & 61 耳
\end{tabular}


性閉鎖する意義は少ないと考える.中耳炎が上 鼓室型でなく耳管型の場合のみ耳管鼓室口を骨 性に閉鎖をはかるかどらかを考えるべきであろ 5 .

\section{3. 手術法と再発}

表 6 は耳管鼓室口の閉鎖処置は必ずしも良い 結果をもたらすとは限らないことを示している. 残存含気蜂巣の含気，ドレナージがはかられる 必要がある．筆者らはこの解決のために筋膜で 中耳腔を形成する場合もある. 12 耳に施行して 最長 7 年経過したが, 術後の創面も狭くなり乾 燥日数も短縮し，また術後の湿潤例もない。鼓 膜を張らない場合と較べて有意に乾燥がよい (Fischer 直接確率 $\alpha=0.00048$ ).

4. 患側骨導と対側気導の差（術前）

両耳聴効果が期待できない場合根本手術を選 択寸るといら考えではいけないのかといら問題 を考兵てみる．無理に鼓室形成術を行っても， 両耳聴の効果が期待できない場合，伝音系再建 術を強行する意義づけがむずかしいといえる。 たとえば, 補聴器をつかっても左右耳の情報が 融合し難いような場合は実際には対側耳の聴力 のみで日常生活を送っていることになる，両内 耳空に可動性があると仮定して, 両耳聴効果が 期待できる可能性は術側の術前骨導と対側の気 導の差が 25〜30 dB 以内である3). 表 7 から, 27 耳は両耳聴効果の可能性があるが対側が龍あ るいは $41 \mathrm{~dB}$ 以上の骨導低下のため実用聴力が 期待できないといら理由で根本手術を選択せざ るを得なかったといらことになる。

5 . 中耳根本手術症例の推移

上述の結果を考慮して，耳管豉室口を骨性に 閉鎖した時代に続き閉鎖をやめた時代があり現 在では積極的に中耳腔を再建するメリットを考 慮した手術に移行した様子が図 2 によく示され ているただし，1987年，1988年には耳管鼓室 口閉鎖例が 3 例ある．これは耳管鼓室型の中耳 炎で最近では少なくなったがまだあることを示
している.このよらに根本手術は減少している がな拉該当症例があるので過去の術式として忘 却されてはならない.

6. そのほか

外耳道の処置は後壁を除去するだけでは不十 分である. 乳突削開創面の底部は術後外耳道か ら完全に視野に入るようにする. 死角部に痂皮 の貯留, 感染を起こすからである. この解決に は外耳道下壁も削開する必要がある。

\section{おわりに}

近畿大学医学部耳鼻咽喉科学教室の開講15周 年に際して中耳根本術症例を検討した. 中耳根 本術は残存蜂巣のため炎症を抑える手術として は欠点がある，聴力上は両耳聴力が期待できな い場合選択してもよい, 上咽頭, 鼻副鼻腔炎が 少なくなった現在耳管鼓室口を骨性に閉鎖する 意義が乏しくなっている，耳管を開いて中耳腔 を創った方が術後創の乾燥がよい, などの結果 を得た。 以上の結果から, 伝音系再建を行ら意 義が乏しく中耳根本手術を施行する例にも中耳 腔再建を行らことを考えた注らがよい，と結論 する。

本論分の内容の一部は第 16 回日本臨床耳科学会 （1988年11月, 京都）で口演した.

\section{参考文献}

1) Rambo JHT : Mastoid surgery. Effect of ratained mucosa on healing. Ann Otol $88: 701$ $\sim 707,1979$.

2) 湯浅 涼: 真珠腫に対する手術; 外耳道を削除 する立場から. 日耳鼻 $88: 1505 \sim 1506,1985$.

3）太田文彦：慢性中耳炎の保存療法における聴力 の問題. 耳鼻臨床 $63: 27 \sim 31,1970$.

$$
\left(\begin{array}{l}
\text { 別刷請求先 : 村田 清高 } \\
\text { 干5 } 59 \text { 大阪狭山市大野東377-2 } \\
\text { 近畿大学医学部耳鼾咽喉科学教室 }
\end{array}\right)
$$

